\title{
Report of 10 operations under local cerebral hypothermia
}

\author{
BERNARD N. WILLIAMS'1 AND ERIC A. TURNER \\ From the Queen Elizabeth Hospital, Birmingham
}

SUMMARY A method of local cerebral hypothermia with circulatory arrest of one or more of the major vessels of the neck is described. Ten clinical cases have been operated upon, and much has been learned of the operative difficulties including an increased operating time and a high complication rate. There were four post-operative deaths, in one (case 1) there was some evidence that the technique protected the perfused part of the brain from anoxic damage. In case 9 the method itself caused particularly bad operating conditions and eventually the patient died. Case 2 and case 4 , like case 1, were patients who were severely ill and who might well have died whatever technique had been used in operating upon them. Of the survivors, one patient (case 3) had a post-operative intracerebral clot which developed during closure and another (case 6) had an intracerebral clot which required removal after 24 hours. Another patient (case 8) had some delay in return to full mental function. In the light of this experience we cannot regard the method in its present form as satisfactory for general use. In our view, its further development requires the discovery of a more effective means of neutralizing the anticoagulants, or doing without anticoagulants altogether. It is also necessary to develop a method of monitoring parts of the brain distant from those directly perfused to give warning of threatened anoxia. Until such time as these problems can be solved we have returned to other procedures but are publishing our results in the hope that other workers will be able to improve upon them.

Since the work of Drew (1959), neurological surgeons have been interested in using the ability of the brain to withstand complete circulatory arrest for over 30 minutes at temperatures of the order of $15^{\circ} \mathrm{C}$, on the basis that the difficult aneurysm or arteriovenous malformation might be easier to treat under such conditions.

From the beginning it seemed probable that the full Drew technique might be too much for a patient who had sustained one or more recent subarachnoid haemorrhages. Despite the difficulties, a large number of neurosurgical operations were carried out in the early 1960 s and clinical reports came from Diaz, Rábago, and Obrador (1961), Neville and Kameya (1961), Guiot (1962), Patterson and Ray (1962), Small (1962), Uihlein (1962), Rehder, Kirklin, MacCarty, and Theye (1962) and Drake, Barr, Coles, and Gergely (1964). Most of the series were small, indicating general dissatisfaction with the method.

${ }^{1}$ Present address and for reprints: Hull Royal Infirmary, Hull
Local cerebral hypothermia by perfusion had been reported for cardiac surgery by Kimoto, Sugie, and Asano (1956) and Vishnevsky (1961). The most successful clinical series has come from Kristiansen, Krog, and Lund (1960), and Kristiansen, K. (1963) who applied regional cerebral hypothermia through one carotid without attempting total circulatory arrest.

The present study arose from a desire to compromise between the two techniques. It was proposed to achieve a local temperature around $15^{\circ} \mathrm{C}$ without direct interference with the heart. We proposed withdrawing oxygenated blood from an artery, cooling it, and perfusing it distally up one carotid artery at a pressure above systemic arterial pressure. As the temperature of the perfused hemisphere fell, overflow into the opposite carotid territory plus cooling by conduction would cool the other hemisphere to a point at which it would be safe to occlude the opposite carotid artery, and as the intracranial temperatures fell further, then the vertebral arteries might be safely occluded one by one. Thus the brain 
would be cooled and its oxygen requirements met through one artery which would be under direct surgical control.

Parkins, Jensen, and Vars (1954) in a study of experimental brain cooling noted that brain damage was always present below $12^{\circ} \mathrm{C}$. Connolly, Harris, Bruns, Smith, Guernsey, and Boyd (1960) found evidence of histological damage to the Purkinje cell layer of the cerebellum after cooling, even when circulatory arrest had not been used. This was present in all their dogs, including those who had apparently made a complete recovery. They also thought that carotid flow rates above $10 \mathrm{ml} . / \mathrm{kg} / \mathrm{min}$ in dogs were injurious. Woodhall and Reynolds (1958) expressed the same opinion, plus the belief that arterial perfusion pressure must not be allowed to rise much above systemic arterial pressure.

The possibility of anoxic damage due to hypothermia itself exists chiefly because of changes in the blood and because of possible inadequacies in the blood vessels. Our experimental work on the dog has previously been reported (Williams, 1964b) and a full discussion of the irregularities in cooling which we called 'rewarming humps' is presented there. We feared that these irregularities were caused by an active element of vascular contraction in response to cold.

There is considerable support in the literature for the idea that cold blood causes vasoconstriction as it passes into the serebral circulation. Florey commented on cortical vasoconstriction due to cold in 1925. Rosomoff and Holaday (1954) suggest a two to threefold increase in cerebral resistance at $25^{\circ} \mathrm{C}$ in dog brains. Senning and Olsson (1957) and Woodhall and Reynolds (1958) have found increased resistance during perfusion cooling.

Lund, Johansen, Krog, and Birkeland (1958) noted evidence of arterial vasoconstriction when cold blood was perfused into the carotid arteries of dogs and found that carbon dioxide and trimetacamphorsulphate (Arfonad) were partially protective. Misko (1965) also observed evidence of vasoconstriction which could be lessened by introduction of papaverine into the perfusion apparatus. Periods of alternate dilatation and constriction occur in the digital arteries of fingers exposed to cold (Lewis, 1930). Similar findings have been reported from arteries in peripheral nerves by Keatinge (1958). Our own 'rewarming humps' bear a close resemblance to the swings of temperatures reported by Lewis and it is of interest that they occur mostly between $30^{\circ} \mathrm{C}$ and $20^{\circ} \mathrm{C}$.

The well-known and feared association of cerebral vascular 'spasm' with subarachnoid haemorrhage might have made us hesitate to use a technique which appeared to cause 'spasm' of itself. However there is no evidence that the 'spasm' seen after subarachnoid $z$ haemorrhage is the same as 'spasm' after cooling $\stackrel{\mathbb{D}}{=}$ and their aetiology, duration, and pharmacological on responses are different. We did not therefore preclude the possibility of using hypothermia when 0 'spasm' due to haemorrhage was present. There were wo indeed two possible advantages: a temporary improvement in oxygen deficit due to the lessened oxygen demand and a cessation of any active element in the vessel wall causing the vessel to be narrowed.

Apart from suspicions of vasoconstriction, definite conclusions which we were able to draw from our own experimental work were:

1. Regional cerebral hypothermia to temperatures below $12^{\circ} \mathrm{C}$ could be carried out on the dog with a $\nRightarrow$ very reasonable degree of safety and sometimes without evidence of histological damage using our technique.

2. Low molecular weight dextran (Rheomacrodex) when used to prime the extracorporeal apparatus, had a marked effect in increasing flow to all the tissues of the head during regional cerebral $\underset{\omega}{\omega}$ hypothermia and its use probably lessened the $r$ chances of damage to the microcirculation (Löfstron 1959; Edmunds, 1966).

3. The volume changes after the use of Rheoma crodex for priming the extracorporeal apparatus, a reported by Davies, Ricketts, and Williams (1963) were convenient for the technique.

4. Halothane abolished the cooling irregularities ('rewarming humps'), and it promoted blood flow to the whole head in the dog under our conditions.

5. Flow rates higher than those given in the literature were acceptable without producing brain damage, provided that perfusion was carried out at constant pressure and not using a fixed flow system.

6. Rapid cooling of up to $1.5^{\circ} \mathrm{C}$ per minute was not harmful provided that halothane, Rheomasrodex, additional carbon dioxide, and constant pressures perfusion were used.

The use of this technique for clinical cases was begun after the experimental work had progressed as far as could be judged useful-that is to say, that a temperature below $15^{\circ} \mathrm{C}$ with survival could virtually be guaranteed in the dog.

\section{METHODS}

The basic circuit was derived from that shown in Fig. 1. The method of cannulation used in the majority of cases is shown in Fig. 2. Heat exchange was carried out through $D$ a stainless steel heat exchanger initially, but in later cases we used a self-supporting polyvinyl chloride (PVC) coil $N$ immersed in a bath of ice and brine (Abrams and $S$ Williams, 1964).

The 'sash' method was used, investing a $\frac{1}{4}$ in. $(6 \cdot 4 \mathrm{~mm})$ 


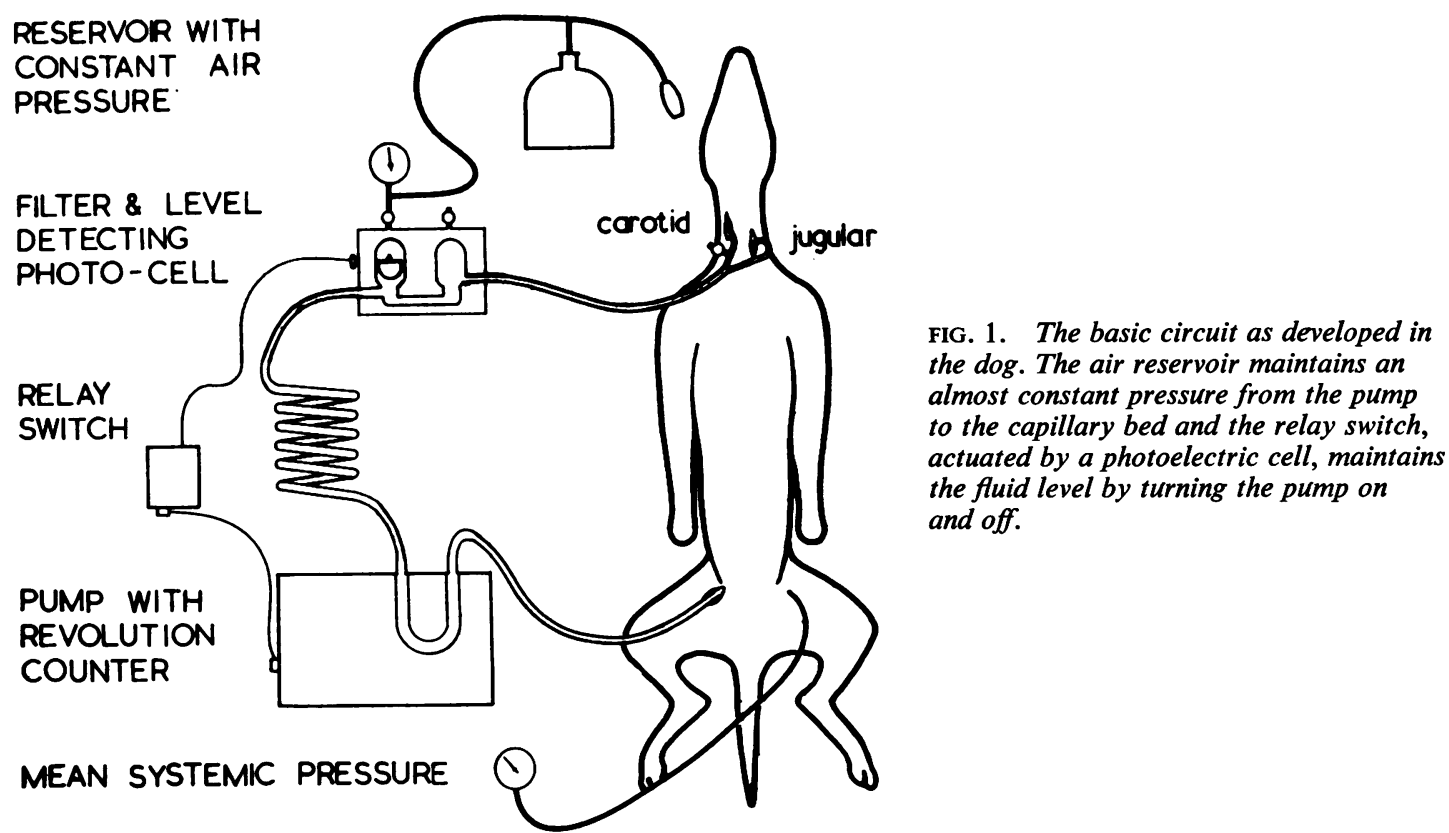

diameter PVC loop in 'layflat' nylon tubing, sterilizing it and then, after the circuit had been assembled and primed, dividing both the sheath and the line under sterile conditions. The loop was thereby divided into a proximal line connected to a catheter taking blood from the heart, and a distal line directed towards the brain.

Cannulations were carried out using Genito-Urinary Company adaptors and Bardick plastic catheters. The patient's body was warmed throughout the period of local cerebral cooling by the use of circulating blankets. At the start of the procedure these blankets were used to provide some cooling so that extra safety was available during carotid cannulations and because it was then easier to lower the brain temperature below $15^{\circ} \mathrm{C}$. Monitoring was carried out using intra-arterial pressure recordings and an electrocardiogram. Thermocouples

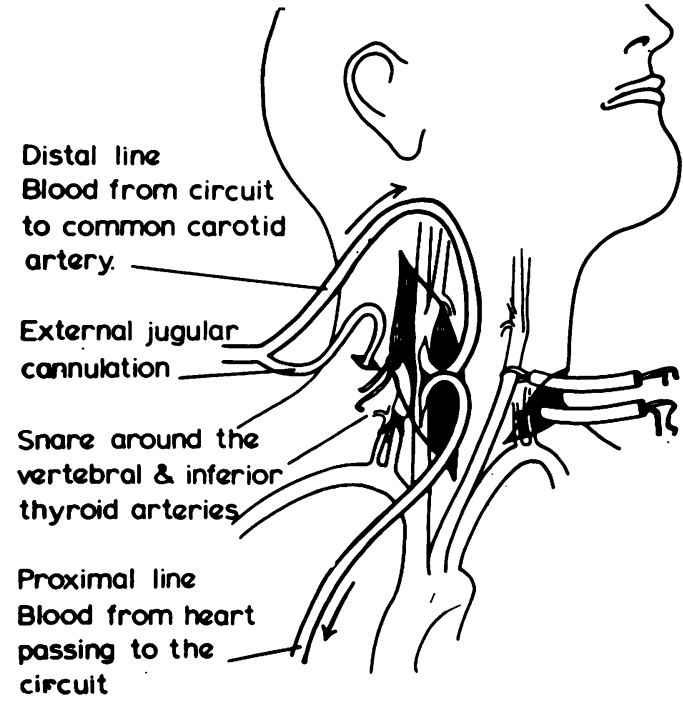

's"nylon tape to occlude the common carotid and vertebral and inferior thyroid arteries.
FIG. 2. Scheme to show method of cannulation in the later cases in which the full method was used. The distal cannula could be pushed into the internal if required. 
were placed into the oesophagus level with the heart, and in the rectum, on a metal tube transmitting the perfusate to the distal line, in the jaw muscles of both sides, and sometimes in various positions in the operative exposure.

Perfusion was carried out at constant pressure rather than with a constant flow rate. A combined filter and bubble trap modified from that described by Krog, Lerand, Kristiansen, B., and Kristiansen, K. (1962), was fitted with a light source and a photoelectric level sensing device which controlled the roller pump. The pressure $Z$ was set at around $20 \mathrm{~mm} \mathrm{Hg}$ above the mean systemic $\stackrel{\varnothing}{\triangle}$ pressure and rarely required readjustment during the procedure. The apparatus is fully described in a separate paper (Williams and Lightwood, 1970).

\section{RESULTS}

The ten clinical cases are summarized in Table 1.

TABLE

SUMMARY OF CLINICAL OPERATIONS

\begin{tabular}{|c|c|c|c|c|c|c|c|c|c|c|}
\hline No. & Age & $\begin{array}{c}\text { Weight } \\
(\mathbf{k g})\end{array}$ & Pathology & $\begin{array}{l}\text { Lowest } \\
\text { recorded } \\
\text { brain } \\
\text { temperature } \\
\left({ }^{\circ} \mathrm{C}\right)\end{array}$ & $\begin{array}{l}\text { Time } \\
\text { perfused } \\
\text { (min) }\end{array}$ & $\begin{array}{c}\text { Mean } \\
\text { flow } \\
(\mathrm{ml} . / \mathrm{kg} / \mathrm{min})\end{array}$ & $\begin{array}{l}\text { Carotid } \\
\text { artery } \\
\text { perfused }\end{array}$ & $\begin{array}{l}\text { Other } \\
\text { arteries } \\
\text { occluded }\end{array}$ & $\begin{array}{l}\text { Operative } \\
\text { conditions }\end{array}$ & Complications \\
\hline 1 & 61 & 561 & $\begin{array}{l}\text { Left } \\
\text { frontal } \\
\text { glioma }\end{array}$ & $16 \cdot 2$ & 70 & $2 \cdot 85$ & $\begin{array}{l}\text { Right } \\
\text { internal }\end{array}$ & $\begin{array}{l}\text { Left } \\
\text { common } \\
\text { carotid }\end{array}$ & Good & $\begin{array}{l}\text { Unrecognized low BP } \\
\text { Hyperventilation } \\
\text { Death after } 4 \mathrm{hr}\end{array}$ \\
\hline 2 & 52 & 65 & $\begin{array}{l}\text { Right } \\
\text { occipital } \\
\text { glioma }\end{array}$ & $13 \cdot 6$ & 75 & $2 \cdot 60$ & $\begin{array}{l}\text { Right } \\
\text { internal }\end{array}$ & $\begin{array}{l}\text { Both sup. } \\
\text { thyroids } \\
\text { Left } \\
\text { common } \\
\text { carotid }\end{array}$ & $\begin{array}{l}\text { Satis- } \\
\text { factory }\end{array}$ & $\begin{array}{l}\text { Hyperventilation } \\
\text { Death with hypotension } \\
\text { at } 26 \mathrm{hr}\end{array}$ \\
\hline 3 & 62 & 50 & $\begin{array}{l}\text { Left } \\
\text { frontal } \\
\text { glioma }\end{array}$ & $11 \cdot 6$ & 30 & 1.60 & $\begin{array}{l}\text { Left } \\
\text { internal }\end{array}$ & $\begin{array}{l}\text { Left sup. } \\
\text { thyroid }\end{array}$ & Good & 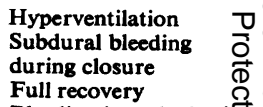 \\
\hline 4 & 46 & 55 & $\begin{array}{l}\text { Left middle } \\
\text { cerebral } \\
\text { aneurysm }\end{array}$ & $12 \cdot 2$ & 66 & $2 \cdot 1$ & $\begin{array}{l}\text { Left } \\
\text { common }\end{array}$ & $\begin{array}{l}\text { Both } \\
\text { vertebrals } \\
\text { and right } \\
\text { common } \\
\text { carotid }\end{array}$ & Good & $\begin{array}{l}\text { Bleeding into the braiñ } \\
\text { during closure } \\
\text { Some improvement } \\
\text { post-operatively but } \\
\text { eventual death }\end{array}$ \\
\hline 5 & 16 & 70 & $\begin{array}{l}\text { Right } \\
\text { carotid } \\
\text { bifurcation } \\
\text { aneurysm }\end{array}$ & $15 \cdot 4$ & 65 & 0.83 & $\begin{array}{l}\text { Right } \\
\text { common }\end{array}$ & None & $\begin{array}{l}\text { Tense } \\
\text { brain } \\
\text { initially }\end{array}$ & None \\
\hline 6 & 34 & 70 & $\begin{array}{l}\text { Anterior } \\
\text { communicat- } \\
\text { ing aneurysm }\end{array}$ & $14 \cdot 7$ & 41 & $4 \cdot 1$ & $\begin{array}{l}\text { Right } \\
\text { common }\end{array}$ & $\begin{array}{l}\text { Both } \\
\text { vertebrals } \\
\text { and left } \\
\text { common } \\
\text { carotid }\end{array}$ & Good & $\begin{array}{l}\text { Venous bleeding } \\
\text { during operation } \\
\text { Haemorrhagic infarct } \\
\text { of frontal pole } \\
\text { requiring lobectomy } \\
\text { after } 24 \mathrm{hr} \\
\text { Full recovery }\end{array}$ \\
\hline 7 & 35 & 73 & $\begin{array}{l}\text { Right } \\
\text { carotid } \\
\text { aneurysm }\end{array}$ & $15 \cdot 6$ & 85 & $2 \cdot 1$ & $\begin{array}{l}\text { Right } \\
\text { common }\end{array}$ & $\begin{array}{l}\text { Both } \\
\text { vertebrals } \\
\text { and left } \\
\text { common } \\
\text { carotid }\end{array}$ & Good & $\begin{array}{l}\text { Low blood pressure } \\
\text { during operation } \\
\text { Horner's syndrome } \\
\text { post-operatively which } \\
\text { resolved leaving patient } \\
\text { perfectly well }\end{array}$ \\
\hline 8 & 59 & 58 & $\begin{array}{l}\text { Right } \\
\text { carotid } \\
\text { aneurysm }\end{array}$ & 13.6 & 58 & $2 \cdot 38$ & $\begin{array}{l}\text { Right } \\
\text { common }\end{array}$ & $\begin{array}{l}\text { Both } \\
\text { vertebrals } \\
\text { and left } \\
\text { common } \\
\text { carotid }\end{array}$ & Good & $\begin{array}{l}\text { Hyperventilation } \\
\text { and respiratory } \\
\text { distress immediately } \\
\text { post-operatively } \\
\text { Delayed recovery } \\
\text { from dementia }\end{array}$ \\
\hline 9 & 51 & 55 & $\begin{array}{l}\text { Bilateral } \\
\text { middle } \\
\text { cerebral } \\
\text { aneurysms }\end{array}$ & $12 \cdot 6$ & 100 & $1 \cdot 27$ & $\begin{array}{l}\text { Left } \\
\text { common }\end{array}$ & None & Poor & $\begin{array}{l}\text { High intracranial } \\
\text { pressure with severe } \\
\text { venous bleeding at } \\
\text { all stages } \\
\text { Post-operative } \\
\text { haemorrhage and } \\
\text { oedema leading to } \\
\text { death after reopening } \\
\text { of the wound and } \\
\text { frontal lobectomy }\end{array}$ \\
\hline 10 & 41 & 68 & $\begin{array}{l}\text { Left } \\
\text { temporal } \\
\text { glioma }\end{array}$ & $19 \cdot 5$ & 55 & 1.95 & $\begin{array}{l}\text { Left } \\
\text { common }\end{array}$ & $\begin{array}{l}\text { Right } \\
\text { common }\end{array}$ & Good & $\begin{array}{l}\text { None } \\
\text { Death from progression } \\
\text { of tumour after } \\
9 \mathrm{mth}\end{array}$ \\
\hline
\end{tabular}


CASE 1

A 61 year old housewife had a history of increasing mental deterioration. On examination she had early papilloedema and a mild right hemiparesis. A left frontal glioma was identified on angiography. At operation local cerebral hypothermia was instituted from the right femoral artery to the right internal carotid artery. The Rheomacrodex was run into the internal jugular vein and back bleeding from the carotid cannulation into the jugular vein was also allowed for a brief period in order to clear any bubbles.

The operative removal of the left frontal lobe was carried out with ideal conditions during a period of low blood pressure. This hypotensive episode was unintentionally prolonged and severe due to a failure of monitoring. The patient never showed a satisfactory recovery post-operatively and died six hours after return to the ward.

Histological examination of the brain showed mild anoxic changes in nerve cells, especially in the Purkinje cell layer of the cerebellum. Ammon's horn, normally equally vulnerable, was not involved, which seemed to indicate that the hypothermia was truly protective and that the perfusing blood was not responsible for the damage, but rather a failure of the vertebral circulation during the period of systemic hypotension.

\section{CASE 2}

A 54 year old miller had a glioblastoma which had given symptoms of two weeks' duration. The patient's condition immediately before operation was poor with some basal pneumonia. Operation was performed under local cerebral hypothermia carried out from the right femoral artery to the right internal carotid. Operative conditions were satisfactory and an extensive removal of the tumour was carried out without excessive bleeding or much difficulty in obtaining haemostasis. During recovery from the anaesthetic, the patient displayed some hyperventilation. There were no abnormalities in the electrolyte balance and the blood pressure was satisfactory, so the cause of the hyperventilation remained unknown. The patient's post-operative course was never satisfactory and he died in a state of peripheral circulatory collapse on the evening of the day after operation. The brain was not available for histology in this case.

\section{CASE 3}

A 62 year old housewife had a history of mental changes for four months which had become severe three weeks before admission. On examination she had papilloedema, a mild right hemiparesis, and dysphasia. Investigations showed a large left frontal glioma. At operation local cerebral hypothermia was provided by tying both the proximal and distal cannulae into a single incision in the left common carotid artery. This procedure was very satisfactory despite the length of the arteriotomy, and lessened the operation time. While the Rheomacrodex was running into the jugular vein and the circuit was being primed with blood, the distal cannula was placed and snared into the internal carotid artery. The right carotid artery was not clamped. The perfusion was stopped at the start of the period of operative removal and the brain was quite slack. During the closure, however, the brain became tight and the dura had to be reopened and a sizeable clot removed from the operation site. The patient was speaking normally and fully ambulant at the time of discharge 10 days after craniotomy.

\section{CASE 4}

A 46 year old housewife had a history of throbbing headaches for four weeks followed by progressive difficulty with memory and speech. On examination she had a mild right hemiparesis and arteriography showed an aneurysm on the left middle cerebral artery with a good deal of associated spasm. On the day after the angiogram the patient showed some clinical deterioration with dysphasia and drowsiness; early papilloedema was present. Eleven days after admission the patient's condition deteriorated further with some neck stiffness and 24 days after admission she had an undoubted further bleed with an epileptic fit. She did not regain consciousness after this and only the left side of the body would respond to painful stimuli. All limbs were flaccid and both plantar responses were extensor. Operation was carried out with perfusion of the left common carotid artery and occlusion of the contralateral carotid and both vertebral arteries during removal of a large intracerebral clot and dissection of the aneurysm. When this had been carried out, perfusion was stopped and the aneurysm was clipped across its base and surrounded by muscle. Operative conditions were very easy for this procedure. The total time of circulatory arrest was five minutes.

The patient's post-operative course was not satisfactory, despite some improvement with a lightening of her conscious level and return of movement to the right side of the body. She did not regain consciousness and died after six days.

\section{CASE 5}

A 16 year old girl had suffered a typical subarachnoid haemorrhage with recurrence 16 days later. On examination she was a little drowsy but otherwise well. Investigations showed both anterior cerebral arteries filling from the left side. The right carotid artery bore an aneurysm at its bifurcation but no filling of the anterior cerebral artery was demonstrated from the right side even with cross compression. Operation was carried out one week after the second bleed and cold blood perfused into the right common carotid artery only. The flow rate accepted by this artery was small compared with those cases where a cross compression response was demonstrable. The operative conditions were imperfect because of some bulkiness of the brain. Lowering the blood pressure by trophenium and moderate hyperventilation improved the conditions to the extent that the aneurysm could be exposed and clipped quite satisfactorily.

The patient's post-operative progress was satisfactory and she returned to work after one month. 
CASE 6

A 34 year old man had a sudden severe headache followed by typical signs of subarachnoid haemorrhage without unconsciousness. A bilocular aneurysm of the anterior communicating artery was operated upon under local cerebral hypothermia. The operative conditions were excellent and the aneurysm was clipped without any difficulty. A graph showing the main events is given as Fig. 3. The post-operative course was complicated by raised intracranial pressure 24 hours after return to the ward. The wound was re-opened and a large haemorrhagic infarct of the right frontal lobe was found with widespread surrounding oedema. The medial portion of

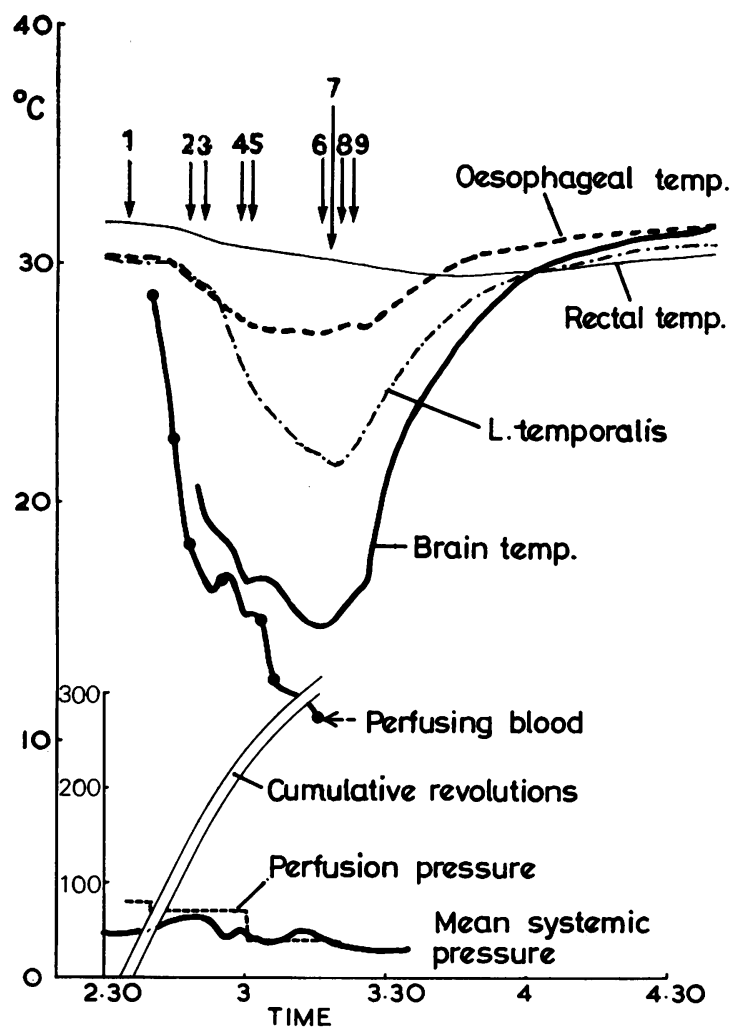

FIG. 3. Graph of the cooling process (case 6). The ascending double line at the bottom is of cumulative revolutions of the pump. The pump output per revolution being known, it is possible to calculate the rate of flow at any one time. The right temporalis thermocouple was not functioning in this case. The period marked at arrow no. 7 is circulatory arrest to the head. It was terminated by simultaneous release of the left vertebral and common carotid arteries. Key to numbered arrows: (1) Perfusion started. (2) Right vertebral occluded. (3) Left common carotid occluded. (4) Testing with line clamped. (5) Left vertebral occluded. (6) Perfusion line clamped. (7) Arrest. (8) Left-sided vessels released. (9) Right vertebral released. the frontal pole was removed. After this the patient's $\bar{Z}$ progress was perfectly satisfactory. He returned to work and subsequently gained promotion.

\section{CASE 7}

A 35 year old Jamaican male had a subarachnoide haemorrhage from an aneurysm on the right carotid artery in the posterior communicating position. There were no localizing neurological signs at any stage and he made a rapid recovery. Five weeks after the haemorrhage he was operated upon using local cerebral hypothermia and the operative exposure, clipping of the aneurysm and the post-operative course were perfectly satisfactory.

\section{CASE 8}

A 50 year old housewife had a severe subarachnoid haemorrhage with unconsciousness for 36 hours. After this she was unwell with attacks of severe right-sided. headache sometimes accompanied by vomiting and one $\vec{\overrightarrow{ }}$ epileptic attack. On examination she was hypertensive ${ }_{\mathcal{O}}$ and very nervous. A large and irregular aneurysm of the right carotid artery was shown arising at the origin of the posterior communicating artery. Operation under $\omega$ local cerebral hypothermia was carried out eight months $\omega$ after the haemorrhage. Occlusion of all four vessels was practised. The perfusion was stopped for two minutos + before the other vessels were released. This allowed the aneurysm to be clipped easily despite its size. Po\$operatively this patient showed some hyperventilation, and subsequently remained drowsy for about two weeks. After three weeks she was fully alert and well orientateg, $\frac{\rho}{\partial}$ although intelligence testing after a month showed a fallo in performance IQ. Over the succeeding months she became quite normal and returned to an active life.

\section{CASE 9}

A 53 year old man had a subarachnoid haemorrhage with loss of consciousness for several hours. He had a right- $\bar{O}$ sided subhyaloid haemorrhage and a mild right facial ֻ

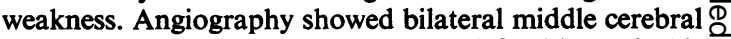
aneurysms. The larger was on the left side and this $\vec{F}$ aneurysm was operated upon using local cerebral hypo-응 thermia three months after the haemorrhage. Crosscirculation as tested during angiography was inadequate and therefore only the left common carotid artery was perfused and the vertebral arteries were not exposed. The operative conditions were difficult from the start. There was a considerable degree of brain swelling with $\overline{0}$ congestion of the veins. The aneurysm was exposed and, 3 when the hemisphere temperature was around $12^{\circ} \mathrm{C}$, the $\bar{\rho}$ main stem of the middle cerebral artery was occluded by a temporary clip. The aneurysm sac was very thin and

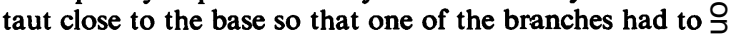
be sacrificed in order to clip the neck securely. After the $D$ temporary clip had been removed, the left frontal lobe was noted to be swollen and bruised as a result of re- $\mathrm{N}$ traction.

On the following day the patient showed evidence of $\mathrm{N}$ raised intracranial pressure so the wound was re-opened

\section{旁}


under general anaesthesia and a fairly large clot was removed from inside the frontal lobe. However, despite this and vigorous measures to control the intracranial pressure, he died some hours later.

Post-mortem examination showed a widespread softening of the left side of the brain with extensive haemorrhage into the substance of the hemisphere extending deeply into the basal ganglia. Throughout both hemispheres there were strips of cortical infarction measuring up to $7 \mathrm{~cm}$ in length. They were particularly marked in the right occipital region.

\section{CASE 10}

A 31 year old man had a three week history of diplopia and headache and showed some slurring of speech and memory loss. Investigations showed a large tumour in the left temporal lobe. Operation under local cerebral hypothermia was carried out perfusing the left common carotid only; the blood pressure was kept low with the aid of additional trophenium and hyperventilation. The right common carotid artery was occluded after 15 minutes of cooling. The operative conditions were excellent and, with a systemic blood pressure of $40 \mathrm{~mm}$ $\mathrm{Hg}$ and the perfusion turned off, no embarrassing bleeding took place during removal of the bulk of an anaplastic astrocytoma. This limited circulatory occlusion was maintained for 10 minutes, after which the right carotid artery was released. Post-operatively the patient's progress was perfectly satisfactory and he was asking to go back to work within one month.

\section{DISCUSSION}

We found that this procedure was both more difficult and more dangerous than we initially envisaged.

The operations always took considerably longer than we had hoped. It was impossible to perform all the arterial manipulations and get perfusion well under way in the time which is normally required to cut a craniotomy flap, besause when an hour or so of perfusion has to be undertaken with no prospect of further access to the exposed carotid and vertebral arteries, initial haemostasis has to be meticulous. Packs inserted into a wound are quite inadequate in the face of high dosage of Rheomacrodex, halothane, and heparin. Dissection and control of all four vessels therefore always took more than an hour. The greatest difficulty was to secure the small veins around the vertebral arteries, which were exposed medially to the carotid arteries. If they bled during perfusion, they were inaccessible once the intravascular catheters were in place. Every vein, therefore, had to be securely diathermied before the perfusion commenced.

Our experimental work did not lead to the development of a satisfactory monitoring technique. Temperature probes could not be inserted into the brain because of the risk of haemorrhage in the presence of heparin, and similar objections applied to the insertion of polarographic electrodes for the measurement of tissue oxygen tensions. In our experience such electrodes were also difficult to calibrate and were inclined to 'drift' unless they were encapsulated with Teflon. The use of flat disc electrodes for measurement of cortical oxygen tension would have been a possible alternative but this would have been restricted to the operative exposure rather than exploring the areas which were at greatest risk of ischaemia-that is, the periphery of the territory normally perfused by the carotid artery into which cold blood was being injected.

Cerebral angiography was used during some of the preliminary experiments on dogs in an attempt to demonstrate the distribution of the perfusate during the period of occlusion of the other three vessels. This method also was found to be unsatisfactory. Multiple exposures on to photographic plates gave a less clear idea of the state of flow than direct observation through the image intensifier. Both these methods were in any event so subjective that we felt it unjustifiable to use them clinically.

The ${ }^{133}$ Xenon method was at first thought to be suitable, since the gas could be introduced into the perfusion line and its rate of clearance studied by external counters positioned before the start of the operation. However, there are theoretical objections to its use in such a highly artificial situation as regional cerebral hypothermia. Adequate analysis of the results demands that a steady state be achieved for several minutes. This was certainly not the situation with our perfusion technique and the method was never carried beyond the experimental stage.

We believed that safety could be provided for our patients by not occluding the contralateral carotid artery unless an adequate cross-filling had been demonstrated on angiography. Provided that blood could reach the anterior end of the circle of Willis on both sides, it seemed unlikely that the posterior communicating arteries would be inadequate to supply a sufficient quantity of blood to the posterior fossa for survival under hypothermic conditions. However, the adequacy of this pathway could not be guaranteed and, although the first vertebral artery could almost certainly be occluded safely in every case, occlusion of the second vertebral artery might be dangerous. In the animal experiments preceding this clinical work it was noticed that after occlusion of the second vertebral artery the respiratory rate sometimes increased in frequency and depth suggesting anoxia. Alternatively, particularly when the vertebral occlusion was not carried out until the whole of the head was cold, the respiration would sometimes decrease considerably in rate without 
increasing in depth. Cooling of the posterior fossa was then thought to be responsible. All the clinical cases in which the vertebral arteries were occluded followed the second pattern and required assisted respiration.

The problem of bleeding exposed a conflict of aims. If all vasoconstrictive influences were opposed in order to take full advantage of every potential anastomosis there was some continuous haemorrhage from all the wounds throughout the time of heparinization and beyond.

Similarly, a conflict of wishes existed over the effect of cerebral blood flow upon brain bulk. The neurosurgeon gained the best operating conditions from a low cerebral blood flow during the early part of the operation and complete arterial occlusion during the final manipulations to the aneurysm. To make the perfusion safe it was desirable to have every vascular channel fully open and the pressures, both systemic and perfusion, adequate to maintain oxygenation of the posterior fossa and the contralateral hemisphere. These conflicting desires were not resolved by a temporary occlusion of circulation because the brain took more than a few minutes to collapse. The firm shrunken brain of a hypothermic, hypotensive, and hyperventilated patient, the sort of brain that K. Kristiansen was able to operate upon, takes a long time to achieve. Not only is the diminution of brain bulk related to the intravascular compartment, but also to cellular nutrition and hydration.

A similar conflict was present in other aspects of the procedure-for example, in the rate of cooling. The use of a high 'gradient' between the perfusate temperature and the brain temperature may have been a factor in provoking cerebral damage in those of our cases which did not recover satisfactorily. This can be suspected from the work of Drew (1961) who noted that when he used a more efficient heat exchanger he began to observe instances of brain damage in children while using a technique which had previously proved quite satisfactory. Damage due to rapidity of cooling might also be suspected in those cases reported by Björk and Hultquist (1960). The possibility of spasm being partly responsible for this damage has been discussed (Williams, 1964a). Because of these suspicions and the evidence for variability of calibre of the vessels which was revealed by our own experimental studies as well as those discussed in the introduction, it might be thought that a small differential drop in perfusate temperature should be sought. The result of this would be that the heart temperature would have dropped relatively further by the time that the head temperature was down to low levels. Only by reducing the head temperature quickly would the core temperature remain relatively high. This conflic seems to have been to some extent resolved by the experimental work. Aiming at a drop of around $1^{\circ}$ per minute while maintaining the perfusion pressure slightly above systemic gave good results.

Unfortunately, we have less evidence on which t $£$ assert that comparable methods are equally safe an\$ satisfactory for operations upon the human subject The first three cases enabled us to overcome sonte. of the problems with the technique. There was ne definite evidence that local cerebral hypothermi had contributed to death in the first two cases and io case 1 there was some reason to believe that exerted a protective effect in the territory perfusect? Case 4 was representative of the very worst type of problem associated with subarachnoid haemorrhage्s and the fact that we were not able to save her dif not therefore condemn the method. With the next three cases, all of whom had had a potentially lethat aneurysm but were in good physical condition, w\& felt that the local cerebral hypothermia gave goo operating conditions and contributed to the safet of the operation. With the eighth case it seems almosw certain that there was some damage to cerebray tissues possibly due to the method. With the niptit case the operation must undoubtedly be accound a technical failure. The reason for the initial bri़inin swelling and continuing bad operating conditiens was not identified, since carbon dioxide retent was avoided, the blood pressure was under sagfs factory control, and venous drainage was mot apparently impaired. It is possible that, despite $\overrightarrow{0}$ cautions, air had entered the perfusion apparatusHowever, it is worthy of note that, as in some of Brierley's (1963) cases of cerebral damage afte? cardiac operations, the damage was apparently maximal in the occipital poles and this might be thought a factor against air embolism since bubble would not be expected to produce most damage in dependent parts of the brain.

For the tenth case the operative conditions were in every way satisfactory.

Because of the difficulties and complications tha? we experienced with this technique, we have, for the present, discontinued using it in favour of ope chest circulatory arrest with conventional hypos thermia as advocated by Small and Stephenson (1966). The experience of clinical anaesthetists in management of blood pressure and ventilation dur $₹$ ing conventional hypothermia is now very greate and, although the precise changes in intracraniat haemodynamics may not be known, the empirica. methods employed provide a very real degree of safety (Campkin, 1965). Both of us have subse? quently used the Small and Stevenson method ifs dealing with difficult aneurysms. 
Nonetheless it still seems desirable in principle to find a safe way of achieving deep hypothermia for the brain. The major obstacles at present are the necessity for using an anticoagulant, on the one hand, and on the other the danger of ventricular fibrillation if the whole body is deeply cooled without perfusion techniques. No anticoagulant is available that can be immediately and completely counteracted, so that one type of case in which the method would be of tremendous advantage - namely, the very vascular lesion or the lesion that has recently bled-is made more dangerous by the method itself.

Our thanks are due to Mr. A. N. Guthkelch for many suggestions during revision of the manuscript. The experimental work prior to the clinical series was supported by the Medical Research Council.

\section{REFERENCES}

Björk, V. O., and Hultquist, G. (1960). Brain damage in children after deep hypothermia for open-heart surgery. Thorax, 15, 284-291.

Brierley, J. B. (1963). Neuropathological findings in patients dying after open-heart surgery. Thorax, 18, 291-304.

Campkin, V. (1965). Moderate hypothermia and circulatory arrest for neurosurgical operations. Brit. J. Anaesth., 37, 528-532.

Connolly, J. E., Harris, E. J., Bruns, D. L., Smith, J. W., Guernsey, J., and Boyd, R. J. (1960). An experimental study of the technique and effects of selective brain cooling. Surg. Forum, 11, 405-407.

Davies, J. W. L., Ricketts, C. R., and Williams, B. N. (1963). Plasma volume expansion by rapid infusion of a low molecular weight dextran. Brit. J. Pharmacol., 21, 220-225.

Diaz, J., Rábago, G., and Obrador, S. (1961). Arteriovenous malformation of the brain removed during deep hypothermia and circulatory arrest. Rev. clin. esp., 82, 375-383.

Drake, C. G., Barr, H. W. K., Coles, J. C., and Gergely, N. F. (1964). The use of extracorporeal circulation and profound hypothermia in the treatment of ruptured intracranial aneurysm. J. Neurosurg., 21, 575-581.

Drew, C. E. (1961). Profound hypothermia in cardiac surgery. Brit. med. Bull., 17, 37-42.

Drew, C. E., Keen, G., and Benazon, D. B. (1959). Profound hypothermia. Lancet, 1, 745-747.

Edmunds, L. H. (1966). Prevention of brain damage during profound hypothermia and circulatory arrest with Rheomacrodex. In Rheomacrodex Symposium Report, 2, 32-34. Pharmacia: London.

Florey, H. (1925). Microscopical observations on the circulation of the blood in the cerebral cortex. Brain, 48, 43-64.

Guiot, G. (1962). Application aux lésions cérébrales des méthodes d'arrêt circulatoire avec réfrigération profonde. Ann. Chir. thor. Cardiovasc., 1, 812-813.

Keatinge, W. R. (1958). The effect of low temperatures on the responses of arteries to constrictor drugs. $J$. Phy'siol. (Lond.), 142, 395-405.
Kimoto, S., Sugie, S., and Asano, K. (1956). Open heart surgery under direct vision with the aid of braincooling by irrigation. Surgery, 39, 592-603.

Kristiansen, K., Krog, J., and Lund, I. (1960). Experiences with selective cooling of the brain. Acta chir. scand., Suppl. 253, 151-161.

Kristiansen, K. (1963). Selective brain cooling. Excerpta med. Int. Congr. Ser., 60, 29.

Krog, J., Leraand, S., Kristiansen, B., and Kristiansen, K. (1962). A servo-operated perfusion unit for selective cooling of the brain. J. Oslo Cy Hosp., 12, 238-243.

Lewis, T. (1930). Observations upon the reactions of the vessels of the human skin to cold. Heart, 15, 177-208.

Löfström, B. (1959). Intravascular aggregation and oxygen consumption. Acta anaesth. scand., 3, 41-51.

Lund, I., Johansen, K., Krog, J., and Birkeland, S. (1958). The change in vascular resistance of the dog's brain on perfusion with cold blood and the modifying effect of $\mathrm{CO}_{2}$ and trimetaphancamphorsulphonate (Arfonad). Acta anaesth. scand., 2, 149-163.

Misko, J. C. (1965). Selective cerebral hypothermia: Physiology and technic. Ann. Surg., 161, 378-389.

Neville, W. E., Kameya, S., Oz, M., Bloor, B., and Clowes, G. H. A. (1961). Profound hypothermia and complete circulation interruption. Arch. Surg., 82, 108-119.

Parkins, W. M., Jensen, J. M., and Vars, H. M. (1954). Brain cooling in the prevention of brain damage during periods of circulatory occlusion in dogs. Ann. Surg., 140, 284-289.

Patterson, R. H., and Ray, B. S. (1962). Profound hypothermia for intracranial surgery: laboratory and clinical experiences with extracorporeal circulation by peripheral cannulation. Ann. Surg., 156, 377-393.

Rehder, K., Kirklin, J. W., MacCarty, C. S., and Theye, R. A. (1962). Physiologic studies following profound hypothermia and circulatory arrest for treatment of intracranial aneurysm. Ann. Surg., 156, 882-889.

Rosomoff, H. L., and Holaday, D. A. (1954). Cerebral blood flow and cerebral oxygen consumption during hypothermia. Amer. J. Physiol., 179, 85-88.

Senning, A., and Olsson, P. I. (1957). Changes in the vascular tonus during cerebral and regional hypothermia. Acta chir. scand., 112, 209-219.

Small, J. M. (1962). Personal communication.

Small, J. M., and Stephenson, S. C. F. (1966). Circulatory arrest in neurosurgery. Lancet, 1, 569-570.

Stone, H. H., Donnelly, C., and Frobese, A. S. (1956). The effect of lowered body temperature on the cerebral hemodynamics and metabolism of man. Surg. Gynec. Obstet., 103, 313-317.

Uihlein, A. (1962). Profound hypothermia and circulatory arrest in operations for intracranial aneurysms. Ann. Chir. thor. Cardiovasc., 1, 811-812.

Vishnevsky, A. A. (1961). Soviet information service report.

Williams, B. N. (1964a). Cerebral injury following cardiac operations. Lancet, 1, 221-222.

Williams, B. N. (1964b). Flow considerations in regional cerebral hypothermia. Acta neurochir. (Wien), 12, 102-119.

Williams, B., and Abrams, L. D. (1964). A low-efficiency disposable heat exchanger. Lancet, 2, 736-737.

Williams, B. N., and Lightwood, R. (1970). Unpublished.

Woodhall, B., and Reynolds, D. H. (1958). Localized cerebral hypothermia. Proc. Soc. exp. Biol. Med., 97, 194-195. 